
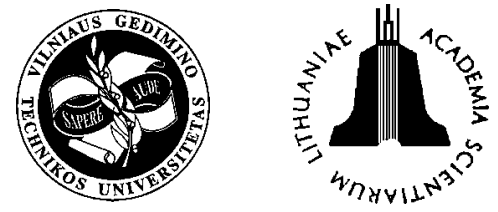

JOURNAL OF CIVIL ENGINEERING AND MANAGEMENT

http:/www.jcem.vgtu.lt

2004, Vol X, No 4, 303-309

\title{
INVESTIGATIONS INTO EFFECTIVE FLY ASH USED IN CONCRETE
}

\author{
Žymantas Rudžionis ${ }^{1}$, Ernestas Ivanauskas ${ }^{2}$ \\ Dept of Building Materials, Kaunas University of Technology, Studentu g. 48, LT-51367 Kaunas, Lithuania. \\ E-mail:1'Zymantas.Rudzionis@ktu.lt,.22Ernestas.Ivanauskas@stud.ktu.lt
}

Received 25 March 2004; accepted 14 Oct 2004

\begin{abstract}
This work presents a study on the influence of thermal-electrical fly ash on the cement paste hydration processes, investigation into cement stone, mortar, ordinary and self-compacting concrete, when cement was replaced by fly ash (5-33\%). It was estimated that cement stone and cement paste prepared from fly ash and cement properties were better when polycarboxylic superplasticiser "Visco Crete-3" was used. It was established that admixture of fly ash influences the processes of cement hydration: the amount of free $\mathrm{Ca}(\mathrm{OH})_{2}$ in cement stone was decreased and amount of stable calcium hydro silicates was increased. It allows to state, that cement stone becomes more corrosion-resistant and more durable. When fly ash admixture is applied in ordinary concrete production, it is possibility to reduce cement expenditures up to $33 \%$ and in self-compacting concrete production, segregation and separation of water decreases. Data of investigations on hardened concrete showed that fly ash increases compressive strength (up to $15 \%$ ), decreases shrinkage strains (up to $31,6 \%$ ), increases plastic deformations (up to $38 \%$ ), modulus of elasticity (up to $15 \%$ ) and modifies other concrete properties.
\end{abstract}

Keywords: self-compacting concrete, fly ash, superplasticiser, hydration processes, compressive strength, shrinkage, durability.

\section{Introduction}

Today one of the most important ecological problems all over the world is utilising the secondary raw materials; one of them is fly ash. About $180 \mathrm{mln}$ tons of thermal-electrical fly ash is collected in the world per year, thus its usage becomes a problem [1]. Reclaiming the fly ash depends on its chemical constituents, granulation and collecting. Chemical activity of fly ash is one of the most important its properties that determines the field of its application [2-4].

Fly ash has been used in civil engineering as a mineral admixture since 1975 [5]. In comparison with other active mineral admixtures, it is more chemically active than rotten-stone, geize and diatomite (less active than fly ash) and cheaper than $\mathrm{SiO}_{2}$ silica fume [6, 7]. Fly ash is collected in cyclones, cyclone piles, wet collectors (scrubbers), and electric filters. It generally consists of earth metal oxides. Chemical constituents can be different; they depend on the type of fuel: $\mathrm{SiO}_{2}-40 \ldots$ $58 \% ; \mathrm{Al}_{2} \mathrm{O}_{3}-21 \ldots 27 \% ; \mathrm{CaO}-4 \ldots 6 \% ; \mathrm{Fe}_{2} \mathrm{O}_{3}-4$ .. $17 \% ; \mathrm{Na}_{2} \mathrm{O}-0,4 \ldots 1,4 \% ; \mathrm{K}_{2} \mathrm{O}-0,4 \ldots 0,7 \%$. Also, it can include some other elements: sulphate, magnesium, titanium, etc [8-10]. Its mineralogical composition includes fused and amorphous quartz, mellite, mullite, crystobalite, hematite, magnetite, lime and other minerals. Some of these minerals in concrete (for example, amorphous $\mathrm{SiO}_{2}$, mellite, $\mathrm{CaO}, \mathrm{MgO}$ ) can have chemical reactions with cement hydration products and compound stable hydrosilicate combinations. That's why fly ash is ascribed to active microfillers group, because the active part of it $\left(\mathrm{SiO}_{2}\right)$ turns into hydrosilicate compounds; the other part, which does not react with binding agents, remains as inert microfiller. Therefore fly ash can be successfully used in ordinary and self-compacting concrete production.

Self-compacting concrete is a concrete that flows by itself, compacts and evenly free forms, not causing segregation and sedimentation of components [11-13]. Recently the self-compacting concrete has been investigated in many scientific institutions and is widely used in construction industry. Because of its large fluidity, it is possible to produce unique constructions having a large amount of steel framework of complicated configuration, fill in all the cavities of the form without vibration. During the design of self-compacting concrete compositions it is necessary to solve some technological problems: concrete mixture must be not disposed to segregation; to obtain low ratio of water and cement with the decrease of cement input; to decrease shrinkage strains; to obtain durable, frost-resistant and water non permeable self-compacting concrete $[14,15]$. The aim of this work is to describe the influence of thermal-electrical fly ash on cement hydration processes and on different properties of cement products. 


\section{Experimental programme}

This research presents the study on the influence of thermal-electrical fly ash on cement paste hydration processes, the investigations of cement stone, mortar, ordinary and self-compacting concrete, when cement is replaced by fly ash (5 to $33 \%$ ).

Materials used for tests: portlandcement CEM I 42,5 $\mathrm{R}$, made in SC "Akmenès cementas", aggregates of Kvesu pit: $4 / 16 \mathrm{~mm}$ fraction gravel, $0 / 2 \mathrm{~mm}$ and $0 / 4 \mathrm{~mm}$ fractions sand, Switzerland firm's "Sika" superplasticiser "Visco Crete-3" 1,48\% of cement mass made on the base of polycarboxyl resin, for cement paste and $0,8 \%$ from cement mass for concrete, plasticiser BV-60 (0,6 \% from cement mass) and fly ash collected in "Balux" firm's (Poland, Bialystok) thermoelectric power station.

X-ray of fly ash was made by ionisation X-ray device diffractometer "DRON-6" (Fig 1). It was determined that synthetic, partly amorphous $\mathrm{SiO}_{2}$ predominates. There is also some hematite and mullite. Mullite mineral shows that fly ash was burned in temperature over $1000{ }^{\circ} \mathrm{C}$. The specific surface of fly ash was established by PSCH-4 (ПCX-4) device. It is $450 \mathrm{~m}^{2} / \mathrm{kg}$. The bulk density of fly ash is $650 \ldots 700 \mathrm{~kg} / \mathrm{m}^{3}$. Hydration degree of cement and $\mathrm{Ca}(\mathrm{OH})_{2}$ amount in cement stone was established by derivatograph of P. Paulik and L. Erdey from MOM firm.

Experimental investigations were carried out in the following order: part of the cement was replaced by fly ash (5-30\%) and hand-prepared cement pastes of normal consistency were made. The samples were $4 \times 4 \times 16 \mathrm{~cm}$ prisms.

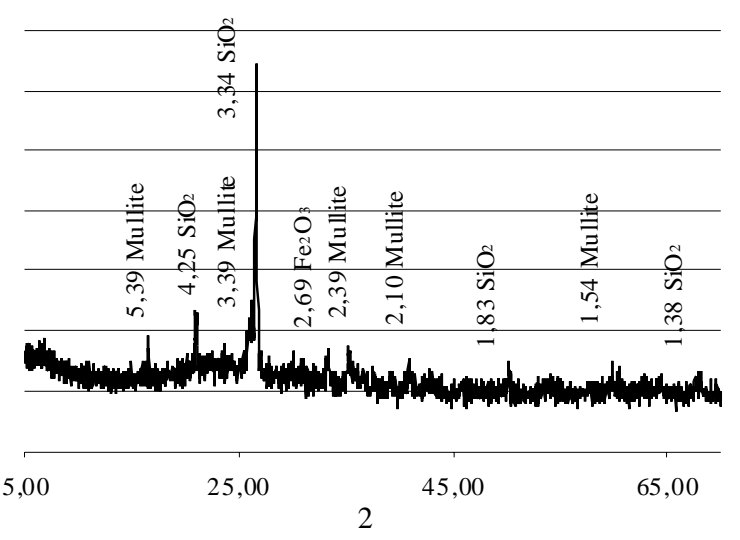

Fig 1. X-ray diagram of the fly ash

Sample prisms $(4 \times 4 \times 16 \mathrm{~cm})$ were made and compacted by vibration (vibration rate $-50 \mathrm{H}_{\mathrm{z}}$, amplitude $0,4 \mathrm{~mm}$ ). After demoulding prisms were cured in a chamber (at $20 \pm 2{ }^{\circ} \mathrm{C}$, relative humidity $95 \%$ ) for 28 days. Samples were taken out of the chamber and kept for $2-$ $3 \mathrm{~h}$ under dry conditions. Then strength of compression and flexure, also water absorption kinetics of cement stone with fly ash admixtures were determined.
Self-compacting and ordinary concrete mixes were prepared in a constrained mixing laboratory mixer, replacing $5 . . .33 \%$ of cement by fly ash. Consistency of self-compacting concrete mixes was kept the same $65 \ldots 67 \mathrm{~cm}$ spread (Fig 2).

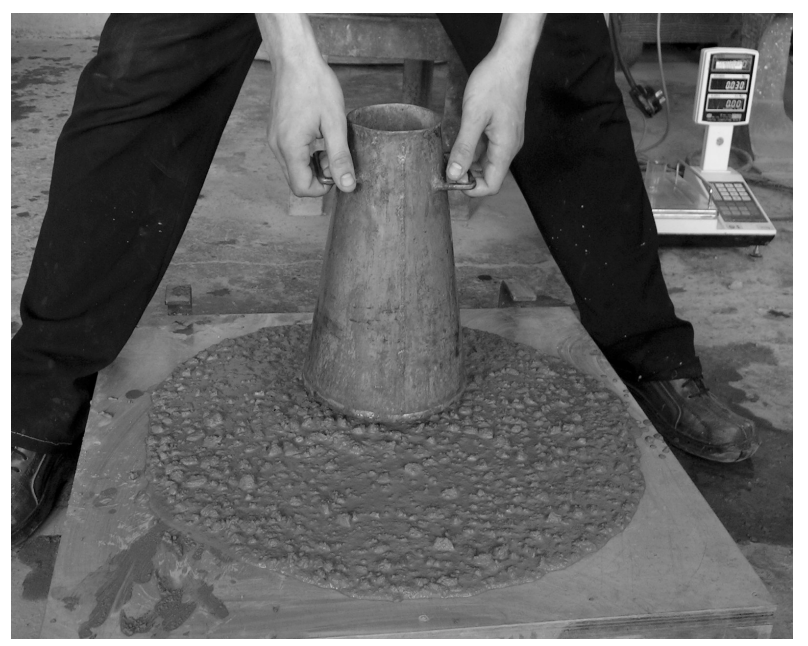

Fig 2. Spread test of self-compacting concrete

Standard cubes of $10 \times 10 \times 10 \mathrm{~cm}$ and prisms of $10 \times 10 \times 40 \mathrm{~cm}$ of self-compacting and ordinary concrete mixes were made and tested for compressive strength, modulus of elasticity and shrinkage strains.

\section{Tests results}

\subsection{The influence of fly ash on cement paste and ce- ment stone properties}

Experimental investigations were performed concerning the influence of fly ash on cement paste and cement stone properties. Part of the cement was replaced by fly ash (5-30\%) and superplasticiser "Visco Crete-3" mixed (1,48\% of cement mass) with water, used for mixing and tests on water requirement in order to get normal consistency of cement paste, strength, density and water absorption kinetics was carried out. Results of the tests are presented in Table 1 and Fig 3.

It was established by the test that replacing cement with major amount of fly ash, the water requirement in order to get a normal paste increases because of a large porosity and specific surface of fly ash. The properties of hardened cement stone with a major amount of fly ash also become worse. That is why it is possible to assume that fly ash has the only role of cement diluents. Mixtures of cement and fly ash prepared using a new generation of polycarboxyle superplasticiser "Visco Crete3 " reduces water requirement in order to obtain normal consistency paste and improves the properties of cement stone with $5 \ldots 10 \%$ admixture of fly ash. The surface strain of cement paste was decreased, flocculus of cement was effectively dispersed, particles of cement and 
Table 1. The matching of cement paste properties with and without superplasticiser

\begin{tabular}{l|c|c|c|c|c}
\hline \multirow{2}{*}{ Cement paste properties } & \multicolumn{5}{|c}{ Amount of cement replaced by fly ash, \% } \\
\cline { 2 - 6 } & 0 & 5 & 10 & 15 & 30 \\
\hline \multirow{2}{*}{ Density, kg/m } & $1951 /$ & $1927 /$ & $1861 /$ & $1797 /$ & $1629 /$ \\
& $1950^{3}$ & $1972^{*}$ & $1900^{*}$ & $1892^{*}$ & $1839^{*}$ \\
\hline \multirow{2}{*}{ Compressive strength, $\mathrm{MPa}$} & $65,2 /$ & $49 /$ & $28 /$ & $23,6 /$ & $22,8 /$ \\
& $58,6^{*}$ & $64,6^{*}$ & $62,2^{*}$ & $57,8^{*}$ & $43,1^{*}$ \\
\hline \multirow{2}{*}{ Flexural strength, $\mathrm{MPa}$} & $7,71 /$ & $9,42 /$ & $8,86 /$ & $7,54 /$ & $5,06 /$ \\
& $12,1^{*}$ & $11,5^{*}$ & $9,19^{*}$ & $8,44^{*}$ & $7,43^{*}$ \\
\hline \multirow{2}{*}{ Water absorption, \% } & $12,1 /$ & $11,9 /$ & $13,1 /$ & $14,4 /$ & $14,9 /$ \\
& $12,8^{*}$ & $12,1^{*}$ & $12,4^{*}$ & $13,1^{*}$ & $13,1^{*}$ \\
\hline
\end{tabular}

* Cement paste was prepared using superplasticiser "Visco Crete-3"

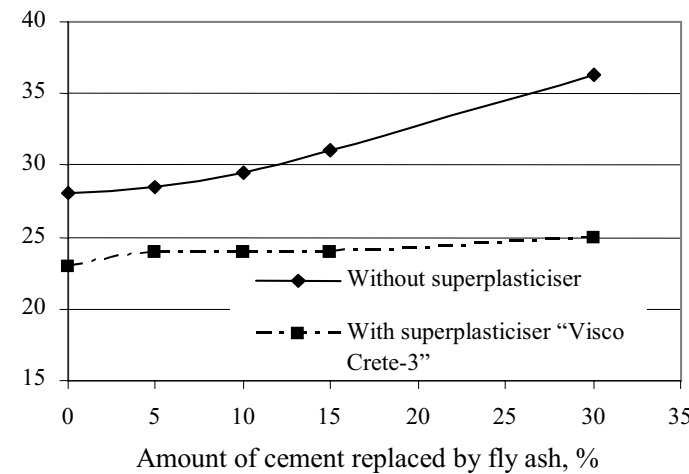

Fig 3. Water requirement dependency on the amount of cement replaced by fly ash

fly ash were mixed homogeneously, when the superplasticiser was used. Therefore, the granulometric composition of the mixture improves; a higher density of cement stone is obtained. Fly ash admixture has no strong influence on cement stone pore properties, but improves the closed porosity and reduces pores, which has a positive influence on cement stone durability.

\subsection{The influence of fly ash on cement hydration products}

For carrying out X- ray and thermographical analyses three types of material samples (cement stone in which portlandcement was replaced by 15 and $30 \%$ fly ash and without it). Before the test the materials were dried at $105^{\circ} \mathrm{C}$ and sieved with No 008 sieve.

When thermographical analysis was made, $\mathrm{Ca}(\mathrm{OH})_{2}$ dehydration endothermic process was clearly seen (line around $500{ }^{\circ} \mathrm{C}$ ). Figs 4,5 show that the increasing amount of fly ash, the amount of free $\mathrm{Ca}(\mathrm{OH})_{2}$ decrease. The results obtained show that a larger amount of fly ash increases the hydration degree of cement stone, $\mathrm{Ca}(\mathrm{OH})_{2}$ support reactions with $\mathrm{SiO}_{2}$ creating new calcium hydrosilicates (line $750^{\circ} \mathrm{C}$ ) and induces deeper hydration of the cement stone.

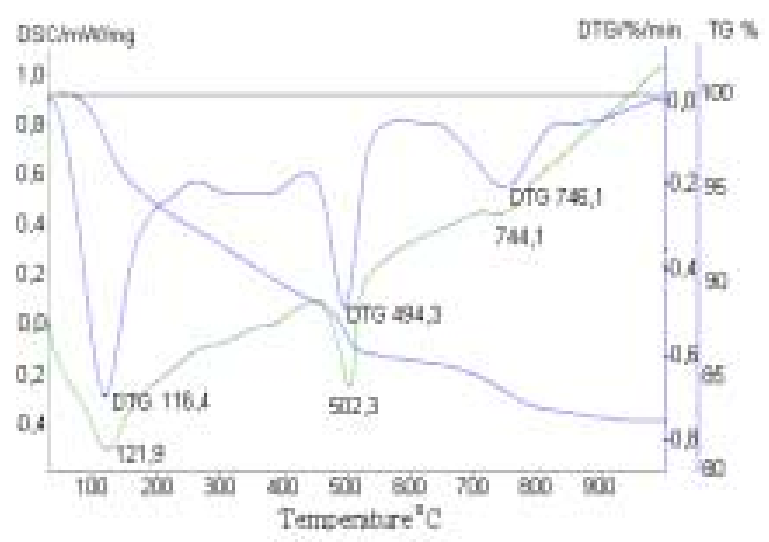

Fig 4. Thermographic analysis, when cement stone is produced without fly ash

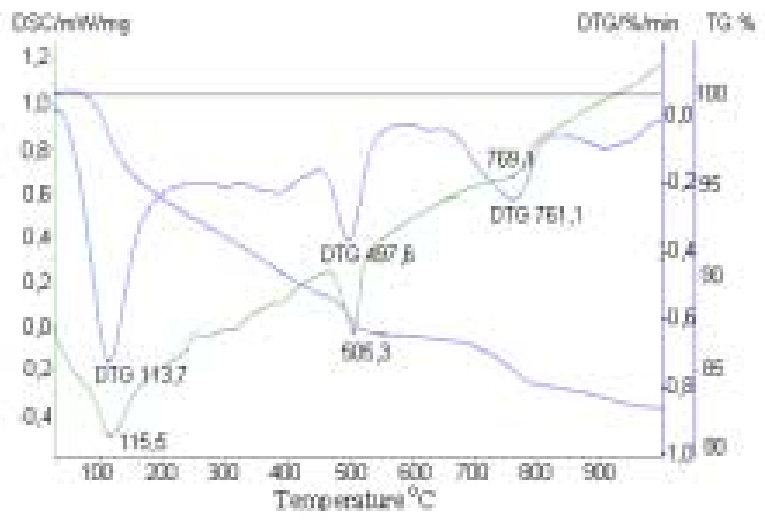

Fig 5. Thermographic analysis when $30 \%$ of portlandcement is replaced by fly ash in cement stone

The obtained X-ray diagrams, with fly ash and without it, are presented in Fig 6. They show that the increasing amount of fly ash in cement stone, the amount of $\mathrm{SiO}_{2}$ increase proportionally (lines $3,34 \mathrm{~A}^{\circ}$ and 2,10 $\mathrm{A}^{\circ}$ ), because there is more than $40 \%$ of $\mathrm{SiO}_{2}$ in fly ash. Increasing amount of fly ash in cement paste, $\mathrm{SiO}_{2}$ actively attaches calcium hydrooxide and forms new calcium hydrosilicates (lines 2,78, 1,83 $\mathrm{A}^{\circ}$ ). Decrease of $\mathrm{Ca}(\mathrm{OH})_{2}$ in cement stone is shown (line $3,11 \mathrm{~A}^{\circ}$ ). 


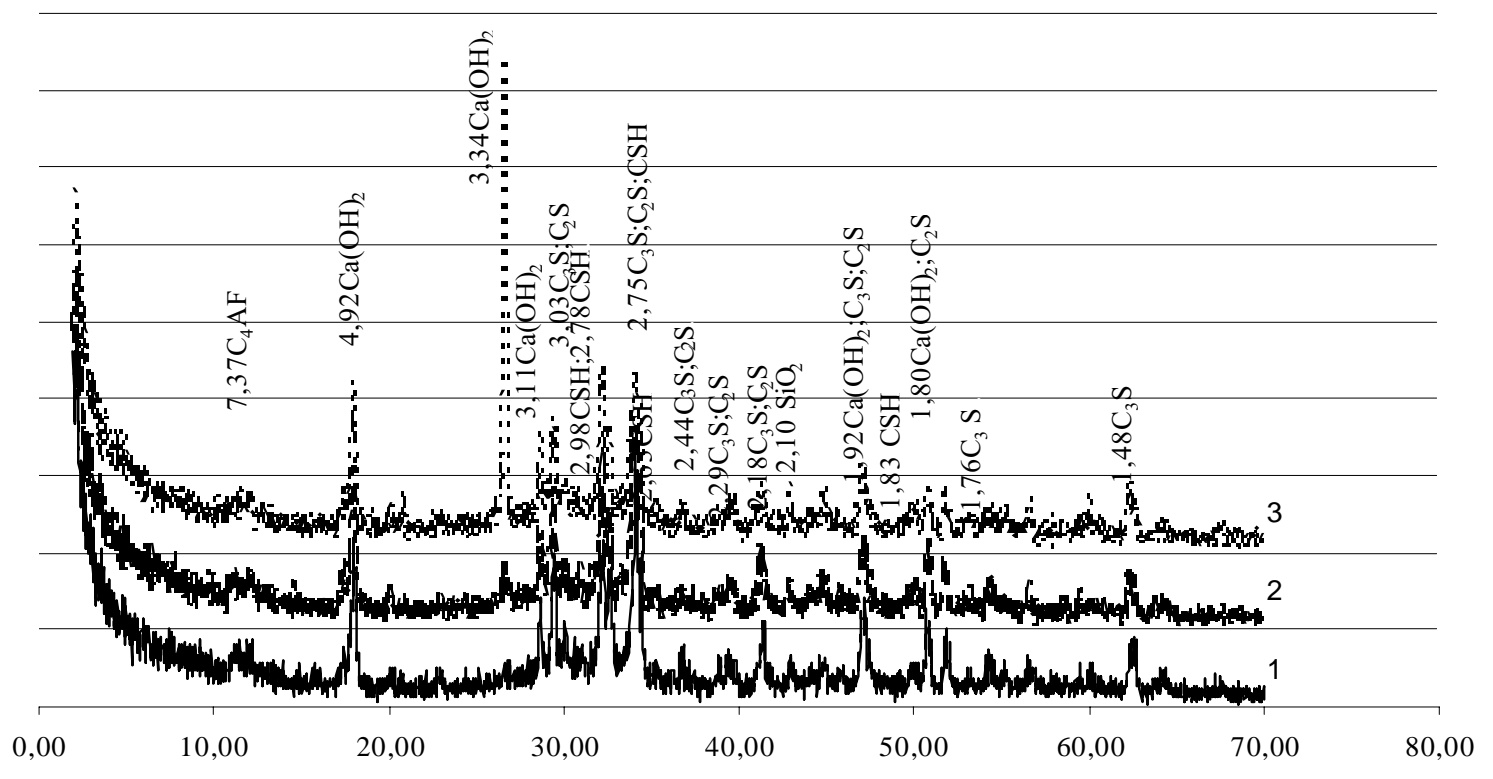

Fig 6. X-ray diagrams of cement stone:

1 - X-ray diagram of cement stone without fly ash;

2 - X-ray diagram of cement stone in which $15 \%$ of cement amount was replaced by fly ash;

3 - X-ray diagram of cement stone in which $30 \%$ of cement amount was replaced by fly ash

\subsection{The influence of fly ash on mortar properties}

The experimental investigations were carried out to estimate the influence of fly ash on the mortar properties, which was made from different coarseness sand. When mortar mixes were preparing, the same rheological properties were kept. There was noticed that when the quantity of fly ash is increasing in the mortar made of cement binder and $0 / 2$ fractions sand, water requirement is increasing for the same slump (when $30 \%$ of fly ash was added, water requirement increased by $60 \%$ ). When coarser sand ( $0 / 4$ fractions) was used, water requirement is stable. When compressive strength tests were made (Fig 7), the strength of mortar prepared from $0 / 2$ fractions of sand decreased, when quantity of fly ash was increased in the mix. But conversely when coarser sand ( $0 / 4$ fractions) was used. Compressive strength was growing up to $10,4 \%$, when $5 \%$ of cement was replaced by

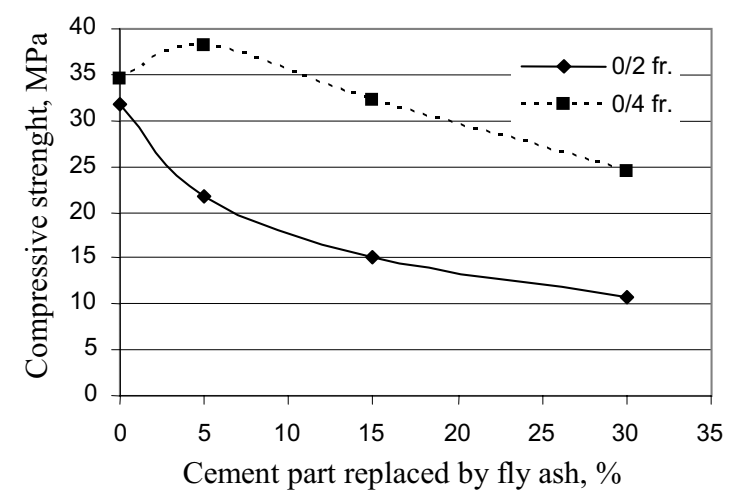

Fig 7. Dependence of compressive strength of mortar with fly ash admixture on sand coarseness fly ash, and with $15 \%$ of fly ash it decreased only by $6,9 \%$. Variation of density, water absorption, porosity properties are similar (Table 2). It is possible to describe this phenomenon that in a coarser sand there is a lack of small particles and admixture of fly ash compensates this lack. In such a case the density of mortar increases, water absorption decreases and with the same consistency mix, improving mortar strength and other properties.

\subsection{Influence of fly ash on the ordinary concrete properties}

C 6/7,5-S1-16 and C 12/15-S2-16 compositions of concrete mixes were chosen for experiments; these compositions are commonly used in concrete mixes producing plants.

When experimental investigations were performed, 15,20 and $33 \%$ of cement was replaced by fly ash in $\mathrm{C} 6 / 7,5$ concrete. The amount of small particles was increased about $30 \%$ in concrete for improving concrete mix consistency. 10 and $20 \%$ of cement was replaced by fly ash in C12/15 concrete and the amount of small particles was kept stable, because its quantity was enough for technological concrete mix preparing.

The investigations results show (Table 3) that compressive strength is decreasing when a part of cement was replaced by thermal-electrical fly ash, but it remain enough for designed compressive strength class of concrete. The plants of concrete mix production are overspending cement for slim compressive strength class of concrete and are producing concrete even several compressive strength class bigger. When fly ash is used for concrete production, there is a possibility to reduce ce- 
Table 2. Properties of mortar with fly ash admixture

\begin{tabular}{c|c|c|c|c|c|c|c|c}
\hline \multirow{2}{*}{$\begin{array}{c}\text { Mortar } \\
\text { properties }\end{array}$} & \multicolumn{6}{c}{ Amount of cement replaced by fly ash, \% } \\
\cline { 2 - 10 } & \multicolumn{4}{|c|}{ Sand fr.0/2 } & \multicolumn{5}{c}{ Sand fr.0/4 } \\
\cline { 2 - 10 } & 0 & 5 & 15 & 30 & 0 & 5 & 15 & 30 \\
\hline Density, kg/m & 2014 & 1917 & 1852 & 1832 & 2164 & 2202 & 2211 & 2110 \\
\hline Water absorption, \% & 7,96 & 8,73 & 10,19 & 11,68 & 5,69 & 5,46 & 5,46 & 6,23 \\
\hline Slump, cm & 6 & 5 & 6 & 7,9 & 6 & 6 & 6 & 8,5 \\
\hline
\end{tabular}

Table 3. Properties of concrete modified by fly ash admixture

\begin{tabular}{|c|c|c|c|c|c|c|c|}
\hline \multirow{3}{*}{ Properties of concrete } & \multicolumn{7}{|c|}{ Amount of cement replaced by fly ash, $\%$} \\
\hline & \multicolumn{4}{|c|}{$\begin{array}{l}\text { Designed C } 6 / 7,5 \text { compressive strength class } \\
\text { of concrete }\end{array}$} & \multicolumn{3}{|c|}{$\begin{array}{l}\text { Designed C } 12 / 15 \text { compressive } \\
\text { strength class of concrete }\end{array}$} \\
\hline & 0 & 15 & 20 & 33 & 0 & 10 & 20 \\
\hline Slump, cm & 0,5 & 1,5 & 4 & 4 & 6 & 4,5 & 5,5 \\
\hline Density, $\mathrm{kg} / \mathrm{m}^{3}$ & 2234 & 2161 & 2176 & 2145 & 2168 & 2161 & 2151 \\
\hline Water absorption, $\%$ & 5,5 & 6,55 & 6,12 & 6,95 & 6,36 & 6,79 & 7,25 \\
\hline Compressive strength, $\mathrm{MPa}$ & 21,08 & 19,7 & 14,31 & 10,86 & 24,59 & 25,5 & 19,38 \\
\hline $\begin{array}{l}\text { Achieved compressive } \\
\text { strength class of concrete }\end{array}$ & $\mathrm{B} 12 / 15$ & $\mathrm{~B} 8 / 10$ & $\mathrm{~B} 8 / 10$ & $\mathrm{~B} 6 / 7,5$ & $\mathrm{~B} 12 / 15$ & $\mathrm{~B} 12 / 15$ & $\mathrm{~B} 8 / 10$ \\
\hline $\begin{array}{l}\text { Frost resistance mark of } \\
\text { concrete }\end{array}$ & F200 & $\mathrm{F} 150$ & F75 & F75 & F200 & F200 & F125 \\
\hline
\end{tabular}

ment expenditures up to $33 \%$ designed slim compressive strength class of concrete production. When $10 \%$ of cement is replaced by fly ash in medium compressive strength class of concrete, there is low-level properties of concrete improvement. Frost resistance is decreased, when fly ash admixture is increased in concrete, but when an optimal quantity of fly ash admixture (up to $15 \%$ ) was used the frost resistance is sufficient. In these cases fly ash using possibilities in ordinary concrete production are obvious.

\subsection{Properties of self-compacting concrete modified by fly ash admixture}

Fly ash was used for self-compacting concrete for reducing the segregation and bleeding. Self-compacting concrete mixes were prepared by using fly ash, replacing cement from $0 \%$ to $30 \%$. Consistency of self-compacting concrete mixes was kept the same $-65 \ldots 67 \mathrm{~cm}$. It was noticed that fly ash did not increase water requirement in order to get the same consistency of concrete mix. This might be explained by the fact that particles of fly ash fit among particles of fine sand, and improve granulometric composition of concrete aggregates, increase density of concrete mix. Water separation or segregation was not noticed in concrete mixes though the input of cement was significantly lower.

Fly ash has different influence on properties of hardened concrete than of cement stone. Fly ash fills gaps because there is a lack of fine particles in Lithuanian aggregates. Fly ash of thermoelectric power stations improves granulometric aggregate composition of concrete,

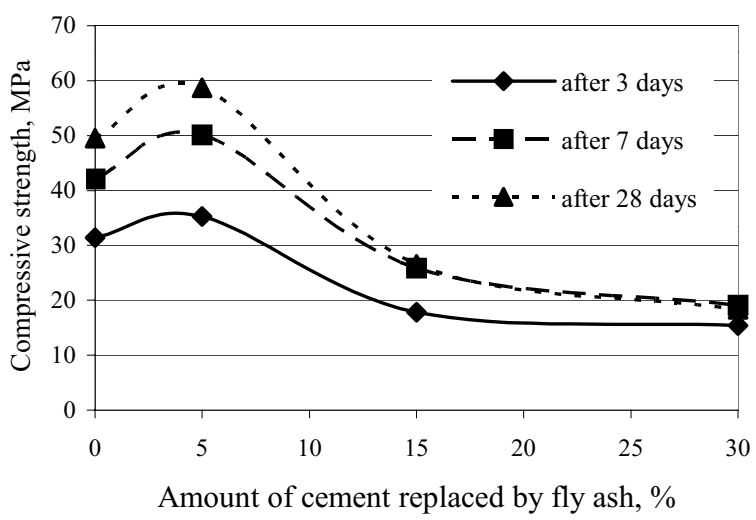

Fig 8. Dependence of concrete compressive strength on the amount of added fly ash

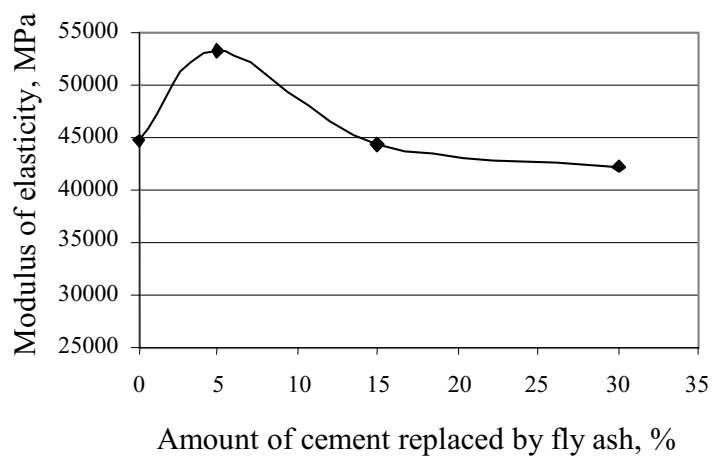

Fig 9. Dependence of concrete elasticity modulus on the amount of added fly ash 


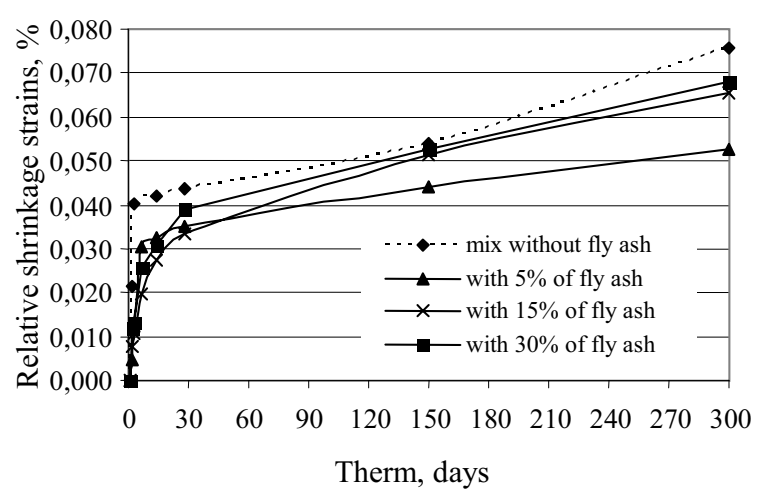

Fig 10. Effect on concrete shrinkage by the amount of added fly ash

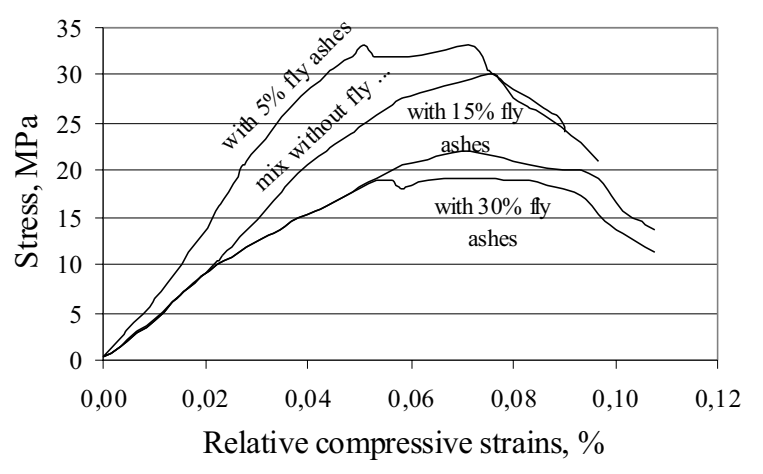

Fig 11. Effect on concrete strain deformations by the amount of fly ash added

increases concrete compressive strength and modulus of elasticity and decrease shrinkage strains (Fig 8, 9). Concrete compressive strength and modulus of elasticity increase, when $5 \%$ of cement is replaced by fly ash. If a larger amount of cement is replaced by fly ash concrete, compressive strength and modulus of elasticity decrease. Also, a tendency is observed that fly ash makes the process of concrete hardening a little bit slower.

The shrinkage strains gradually decrease when part of the cement is replaced by fly ash (5-30\%) in hardened concrete (Fig 10). This might be explained by the process when gel is sticking to parts of fly ash while cement is hardening and when systems drying these parts are taking compression stresses, at the same time developing resistance to shrinkage. It was also observed that hardened concrete, in which part of cement was replaced by $5 \%$ of fly ash, has increased elastic deformations (Fig 11). This means that concrete maintains its elastic properties while larger strains, which allows concrete to return to initial condition when load is removed.

It was also noticed that replacing cement by fly ash (5-30\%) results in larger plastic deformations of concrete (up to $38 \%$ ). This means that concrete with fly ash admixture, increasing stresses remains not crack up longer.

\section{Conclusions}

1. Usage of fly ash without superplasticiser is not effective, because fineness of hard phase is getting up and water needs to cement paste of normal consistence are raised. As a result, properties of cement stone become worse.

2. The major increase of density and strength of cement stone by fly ash $(1,12 \%$ and $9,30 \%)$ and decrease of water absorption (5,50\%), compared with control cement stone, is achieved when $5 \%$ of cement is replaced by fly ash. That is why it is possible to assume that rational replacement of $5 \ldots 10 \%$ cement by fly ash gives an opportunity to improve cement stone properties.

3. Cement stone with an admixture of fly ash can be more durable due to pozzolanic effect of fly ash.

4. For cement mortar production fly ash is best to use, when coarser sand $\left(\mathrm{M}_{\mathrm{cr}}>2,5\right)$ is applied and it has a less quantity of small particles. There is effective to replace $5 \%$ of cement by fly ash in such mortars and their properties are getting adequate.

5. When increasing cement paste amount by fly ash and decreasing cement quantity for small and medium compressive strength classes of concrete production, it is possible to get sufficient concrete properties for designed compressive strength class, to improve concrete mix technological properties and to reduce cement expenditures up to $33 \%$.

6. Usage of fly ash in self-compacting concrete production significantly reduces water separation and segregation. The largest increase in compressive strength and decrease in shrinkage of concrete with fly ash admixture compared with control concrete is obtained when $5 \%$ of cement is replaced. This means that it increases compressive strength (up to $15 \%$ ), decreases shrinkage strains (up to $31,6 \%$ ), modulus of elasticity (up to $15 \%$ ). Therefore it is possible to assume that rational replacement of $5 \ldots 10 \%$ cement by fly ash, provides a possibility to improve concrete properties by decreasing the cement input.

\section{References}

1. Ludwig, H.; Weise F. Self-compacting concrete - principles and practice. Concrete Plant + Precast Technology (Beton+Fertigtel-Technik), No 5, 2001, p. 76-80 (in German).

2. Youjun Xie; Baoju, L.; Jian, Y.; Shiqiong, Z. Optimum mix parameters of high-strength self-compacting concrete with ultrapulverised fly ash. Cement and Concrete Research, Vol 32, No 3, 2002, p. 477-480.

3. Žiogas, V. Microfillers role to few water requirement binding materials and concrete properties. In: Proceedings of the national conference "Building materials and products" (Statybinès medžiagos ir dirbiniai. Respublikinès mokslinès-techninès konferencijos medžiaga). Kaunas: Technology, 1993, p. 143-145. 
4. Goldman, A.; Bentur, A. The influence of microfillers on enhancement of concrete strength. Cement and Concrete Research, Vol 23, No 1, 1993, p. 963-967.

5. Ramachandran, V.; Feldman, R. Science about concrete (Наука о бетоне). Moscow: Stroyizdat, 1986, p. 196-200 (in Russian).

6. Grubl, P.; Lemmer, Ch. Consistency control of self-compacting concrete with particular consideration given to fly ash as concrete additive. Concrete Plant + Precast Technology (Beton+Fertigteil-Technik), No 9, 2003, p. 36-44 (in German).

7. Rudžionis, Ž.; Ivanauskas, E.; Ponelis, T. Influence of fly ashes on the self-compacting concrete properties. In: Proceedings of the conference "Concrete and reinforced concrete” (Konferencijos „Betonas ir gelžbetonis“ pranešimu medžiaga). Kaunas: Technology, 2002, p. 87-92 (in Lithuanian).

8. Ivanauskas, E.; Rudžionis, Ž.; Butkute, R. Investigations of fly ash influence on the cement hydration processes, cement paste and cement stone properties. In: The 5-th international workshop "Advanced materials and technologies”. Palanga: Technology, 2003, p. 35 (in Lithuanian).

9. Bouzoubaa, N.; Lachemi, M. Self-compacting concrete incorporating high volumes of class F fly ash. Preliminary results. Cement and Concrete Research, Vol 31, No 3, 2001, p. 413-420.

10. Mroz, H. The portlandcement modified by fly ashes CEM II/B-V demand and possibilities in construction. In: Learned-Technical Symposium (Sympozium Naukovotechniczne). Poznan-Chorula, 1999. p. 59-75 (in Polish).

11. Stark, J.; Kirmse, J.; Friebert, M. Self-compacting concrete components of use in civil engineering and environmental protection. Concrete Plant + Precast Technology (Beton+Fertigteil-Technik), No 5, 2002, p. 48-50 (in German).

12. Sakata, N.; Yanai, S. Study on new viscosity agent for combination use type of self-compacting concrete. Journal of Advanced Concrete Technology, Vol 1, No 1, 2003, p. $37-41$.

13. Okamura, H.; Ouchi, M. Self-compacting concrete. Journal of Advanced Concrete Technology, Vol 1, No 1, 2003, p. 5-15.

14. Aaron, W.; Hamlin, M. New methodology for designing self-compacting concrete. ACI Materials Journal, Vol 98, No 6, 2001, p. 429-439.

15. Baženov, J. М. Technology of concrete (Технология бетона). Moscow: Vyshaja shkola, 1987. 415 p. (in Russian). 